\title{
Mortality and repellent effects of microbial pathogens on Coptotermes formosanus (Isoptera: Rhinotermitidae)
}

\author{
Maureen S Wright ${ }^{*}$ and Mary L Cornelius ${ }^{2}$
}

\begin{abstract}
Background: Two entomopathogenic fungi, Isaria fumosorosea and Metarhizium anisopliae, and one bacterium, Bacillus thuringiensis, were tested for their ability to cause mortality of Formosan subterranean termites (FST), Coptotermes formosanus (Shiraki), after liquid exposure, and for their lack of propensity to repel FST.

Results: The fungus Isaria fumosorosea at $10^{8}$ spores $/ \mathrm{ml}$ caused $72.5 \%$ mortality on day 7 , significantly higher than the control and $10^{6}$ spores $/ \mathrm{ml}$ treatment. On day 14 , the $10^{6}$ and $10^{8}$ concentrations caused $38.8 \%$ and $92.5 \%$ mortality, respectively, significantly higher than the control. On day $21,82.5 \%$ and $100 \%$ of the termites were killed by the $10^{6}$ and $10^{8}$ treatments, respectively. I. fumosorosea did not repel termites at $10^{6}$ nor $10^{8}$ spores $/ \mathrm{g}$ in sand, soil or sawdust. The fungus Metarhizium anisopliae at $10^{8}$ spores $/ \mathrm{ml}$ caused $57.5 \%$ mortality on day $7,77.5 \%$ mortality on day 14 and 100\% mortality on day 21.

Conclusions: On all three days the rate of mortality was significantly higher than that of the control and $10^{6}$ spores $/ \mathrm{ml}$ treatment with I. fumosorosea. Neither I. fumosorosea nor M. anisopliae caused repellency of FST in sand, soil or sawdust. The bacterium Bacillus thuringiensis did not cause significant mortality on days 7, 14 or 21. When termites were exposed to cells of $B$. thuringiensis in sawdust and when termites were exposed to a mixture of spores and cells in sand, a significantly higher number remained in the control tubes. Repellency was not seen with B. thuringiensis spores alone, nor with the above treatments in the other substrates.
\end{abstract}

\section{Background}

Microbes have been considered as potential control agents for termites, as alternatives and adjuncts to chemical control measures. Termite behavior and grooming mechanisms present limitations to the effectiveness of termite microbial control [1], though it is suggested that combining pathogenic strains with other strains and with insecticides may improve efficacy [2]. Behavior of mound building termites was found to limit spread of an isolate of Metarhizium anisopliae throughout the colony, with repellency being the primary inhibitory factor [3]. A formulation of another strain with reduced repellency was shown to kill nests of Nasutitermes exitiosus termites by baiting in limited field trials. The microbes in this study were chosen because of evidence of their causing

\footnotetext{
* Correspondence: Maureen.Wright@ARS.USDA.GOV

${ }^{1}$ United States Department of Agriculture, Southern Regional Research

Center, New Orleans, Louisiana, USA

Full list of author information is available at the end of the article
}

mortality to termites or other insects and are here screened for their degree of non-repellency.

M. anisopliae, when tested against the subterranean termite Reticulitermes flavipes, was found to cause alarm, aggregation and defensive reactions among termites that were untreated [4]. Other fungi caused a lesser degree of alarm response which was followed by grooming and isolation of the infected termites. In addition, $M$. anisopliae was found to repel the Formosan subterranean termite (FST), Coptotermes formosanus, in tree-based mulches, however some of the repellency may have been attributable to substances from the mulches [5]. Although, potential for M. anisopliae as a control agent for termites was demonstrated when, in a test of eight entomopathogenic strains against the subterranean termite C. gestroi, M. anisopliae was found to be the most virulent [6]. A novel strain of $M$ anisopliae was found to cause significantly greater mortality of FST
C Biomed Central

(c) 2012 Wright and Cornelius; licensee BioMed Central Ltd. This is an Open Access article distributed under the terms of the Creative Commons Attribution License (http://creativecommons.org/licenses/by/2.0), which permits unrestricted use,

distribution, and reproduction in any medium, provided the original work is properly cited. 
alates and workers than a previously commercialized strain [7].

Isaria fumosorosea is an entomopathogenic fungus that has been previously shown to cause significant mortality to FST [8]. I. fumosorosea is formulated in a wettable powder suitable for delivery with keratin foam. The keratin foam was developed as a biologically compatible delivery mechanism for termite microbial control agents $[9,10]$. Species of Paecilomyces sect. Isarioidea are synonymous with Isaria [11].

Bacillus thuringienis is known to produce compounds toxic to some insects and to be pathogenic to others. Because Bacillus strains produce spores there is potential that this microbe will tolerate the nest environment of the termite, and produce infectious propagules in the soil and termite nest environment inhabited by termites. B. thuringiensis Berliner has caused mortality of the termite Nasutitermes ehrhardti [12]. Bacillus isolates have been identified in the gut of C. formosanus, indicating the ability of the genus to survive, and potentially cause mortality of the termite [13].

Termite antennae play a significant role in grooming [14]. Termites without antennae did not remove conidia of I. fumosorosea and M. anisopliae as efficiently as did termites with antennae. Also, termites reared individually were more susceptible to microbial infection than were termites reared in groups and subject to grooming by nestmates $[15,16]$. To effectively control termites using microbes it will be critical to select pathogens that are capable of not only causing mortality but also withstanding detection and removal. Microbial strains that are both virulent and non-repellent have a greater likelihood of being spread within a termite nest and controlling termites in the field. Results are described here for virulence and non-repellency of potential microbial control strains.

\section{Results and Discussion}

A concern when applying microbial control agents is whether they will repel the target insect rather than infect and kill them. Studies with termites in the laboratory show the ability of microbial agents to kill termites, however few of these experiments have been translated to the field $[1,3,17]$. FST are known to remove infected nestmates from the nest and to partition infected areas of the nest and this has the potential to limit availability of inoculum $[1,15]$. By selecting strains of fungi and bacteria that are pathogenic and also not repellent to termites, the probability of applying a microbial agent that functions successfully in the field is increased.

I. fumosorosea is known to cause mortality of insect pests $[8,18]$. A fermentation method was developed to produce stable spores in an inert powder which can be wetted, thereby inducing germination, prior to application
[19]. This powder formulation has been combined with a biologically-compatible foam to permit expansion of the pathogen into the carton nest of termites [9]. Foam expansion increases exposure of termites to the fungal pathogen carried therein. I. fumosorosea was previously shown to kill termites which were exposed directly to the dry formulation powder [8]. To more closely approximate field application of a wet microbial agent, termites were exposed to the spores in a liquid solution, as opposed to a dry formulation. The termites were transferred from the liquid to dampened filter paper, which served as a moisture and nutrient source, for incubation and enumeration of mortality. By day 7 the $10^{6}$ and $10^{8}$ spores $/ \mathrm{ml}$ treatments caused $20.0 \pm 0 \%$ and $72.5 \pm 11.1 \%$ mortality, respectively (Figure 1). Upon calculating the analysis of variance it was determined that the $10^{6}$ treatment was not significantly different from the control which caused $6.3 \pm$ $2.4 \%$ mortality on day 7 . On day 14 , the control had reached $17.5 \pm 4.8 \%$ mortality, while the $10^{6}$ and $10^{8}$ concentrations had reached $38.8 \pm 6.9 \%$ and $92.5 \pm 4.3 \%$, respectively. All three mortality rates were significantly different from each other on day 14 . On day 21 , the $10^{6}$ and $10^{8}$ concentrations caused mortality rates of $82.5 \pm$ $17.5 \%$ and $100 \pm 0 \%$, respectively, which were not significantly different from each other, but they were both significantly different from the control mortality rate of $23.8 \pm 5.5 \%$.

M. anisopliae strain NRRL 30905 was isolated from dead FST alates and was found to be pathogenic to both FST alates and workers [7]. Spores were previously introduced to termites by individual inoculation [7]. Using the liquid exposure method it was found that on day 7 the $10^{8}$ spores $/ \mathrm{ml}$ concentration caused $57.5 \pm 7.5 \%$ mortality, which was significantly higher than the $3.8 \pm 2.4 \%$ and $3.8 \pm 1.25 \%$ mortality exhibited by the control and the $10^{6}$ spores/ml concentration, respectively (Figure 2). On day 14, the control and $10^{6}$ spores/ml concentration were again not significantly different at $6.3 \pm 2.4 \%$ and $7.5 \pm 1.4 \%$, respectively, while the $10^{8}$ spores $/ \mathrm{ml}$ concentration caused $77.5 \pm 13.0 \%$ mortality. By day 21 the $10^{8}$ spores $/ \mathrm{ml}$ concentration had killed $100 \pm 0 \%$ of the termites and the $10^{6}$ spores $/ \mathrm{ml}$ treatment, at $16.3 \pm 4.3 \%$ mortality, was still not significantly higher than the control mortality which was $10.0 \pm 0 \%$ (Figure 2).

B. thuringiensis strain 33679 was selected from a culture collection for evaluation against FST. It was originally isolated from diseased insect larvae. Neither of the Bacillus treatments caused significantly higher mortality than the control on days 7, 14 or 21 (Figure 3). On day 21 the mortality rate was $23.8 \pm 8.0 \%$ for the control, $23.8 \pm 4.3 \%$ for the $10^{6}$ treatment and $23.8 \pm 7.2 \%$ for the $10^{8}$ treatment. On day 7 the control caused $5.0 \pm 3.5 \%$ mortality, $10^{6}$ cells $/ \mathrm{ml}$ caused $7.5 \pm 1.4 \%$ mortality, and $10^{8}$ cells $/ \mathrm{ml}$ caused $10 \pm 2.0 \%$ mortality. On day 14 , the mortality 


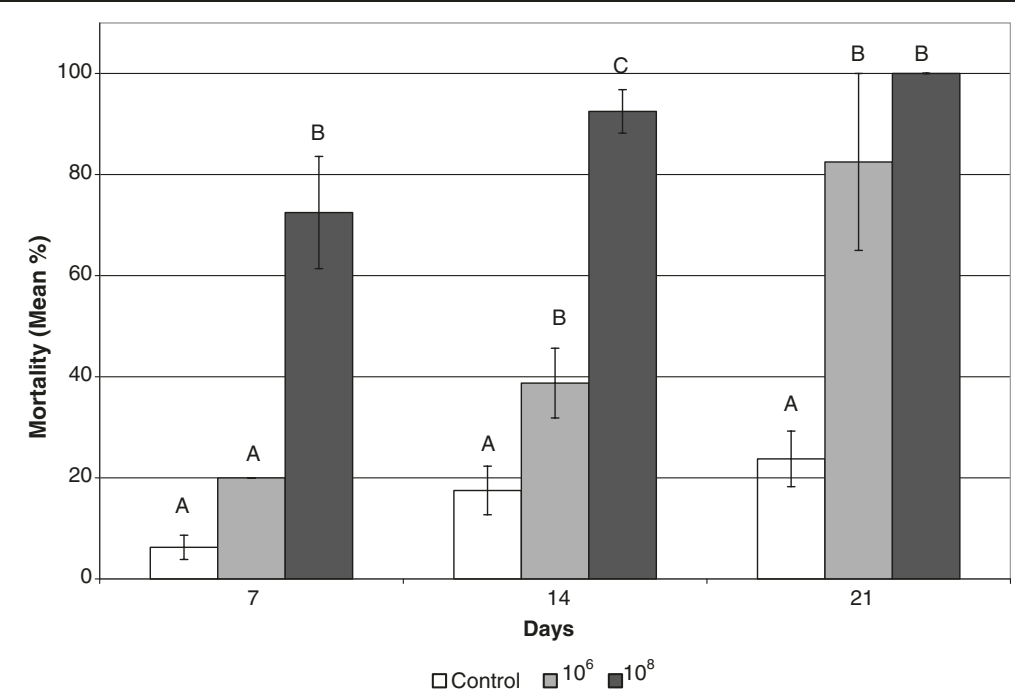

Figure 1 Mean mortality of Formosan subterranean termites by Isaria fumosorosea spore solutions. Bars on the same day with the same letter are not significantly different.

values for the control, the $10^{6}$ and $10^{8}$ treatments were $8.8 \pm 4.3 \%, 11.3 \pm 2.4 \%$ and $13.8 \pm 1.3 \%$, respectively.

Each of the microbial agents was evaluated for the degree of non-repellency toward termites. Non-repellent agents are less likely to be detected and avoided by termites, thereby increasing the probability of causing a pathogenic effect [20]. Termites were tested by exposure to the three microbes in sand, soil and sawdust. The number of FST remaining in tubes containing an entomopathogen was compared to the number of termites remaining in control tubes following $24 \mathrm{hrs}$ in a paired choice test. Repellency was evident by termite foraging behavior in treated arenas differing significantly from termite behavior in untreated controls. Non-repellency was reported as no statistical difference between the numbers of termites in tubes.

There were no significant differences when termites were exposed to I. fumosorosea at either $10^{6}$ spores/g or $10^{8}$ spores/g in any of the substrates (Table 1). At a concentration of $10^{8} \mathrm{M}$. anisopliae spores/g, an average of $12.3 \pm 2.0$ termites remained in the treated sand tubes while $23.0 \pm 5.9$ remained in the controls, but the difference was not significant. With some treatments, ex. I. fumosorosea and M. anisopliae in soil and sawdust, more termites remained in treated tubes after $24 \mathrm{~h}$ exposure than in control tubes, but none of the treatments

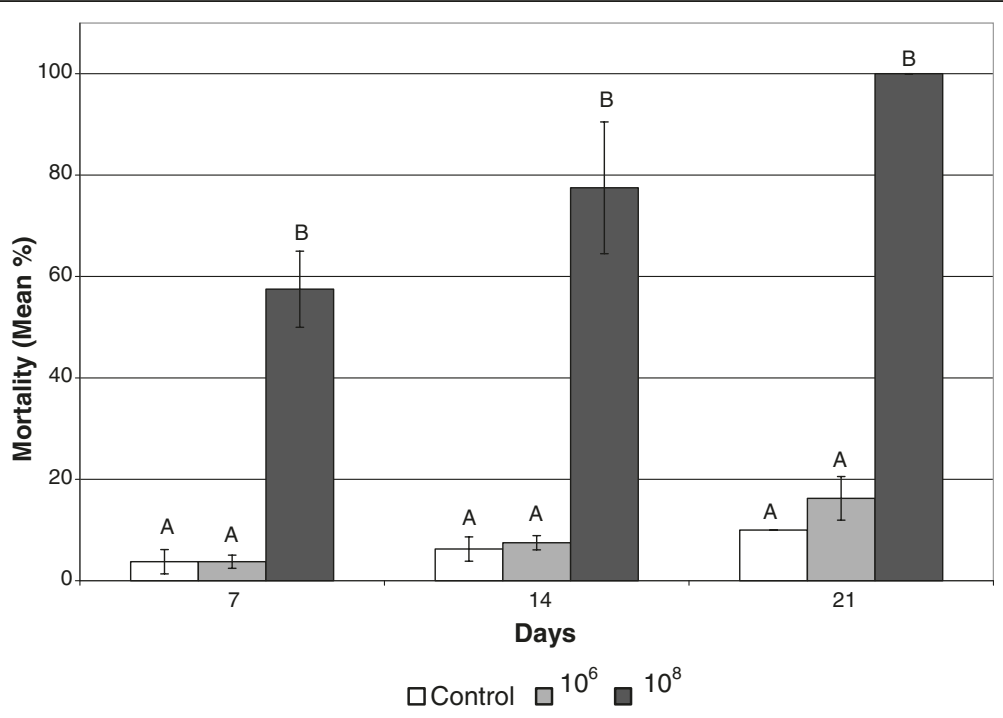

Figure $\mathbf{2}$ Mean mortality of Formosan subterranean termites by Metarhizium anisopliae spore solutions. Bars on the same day with the same letter are not significantly different. 


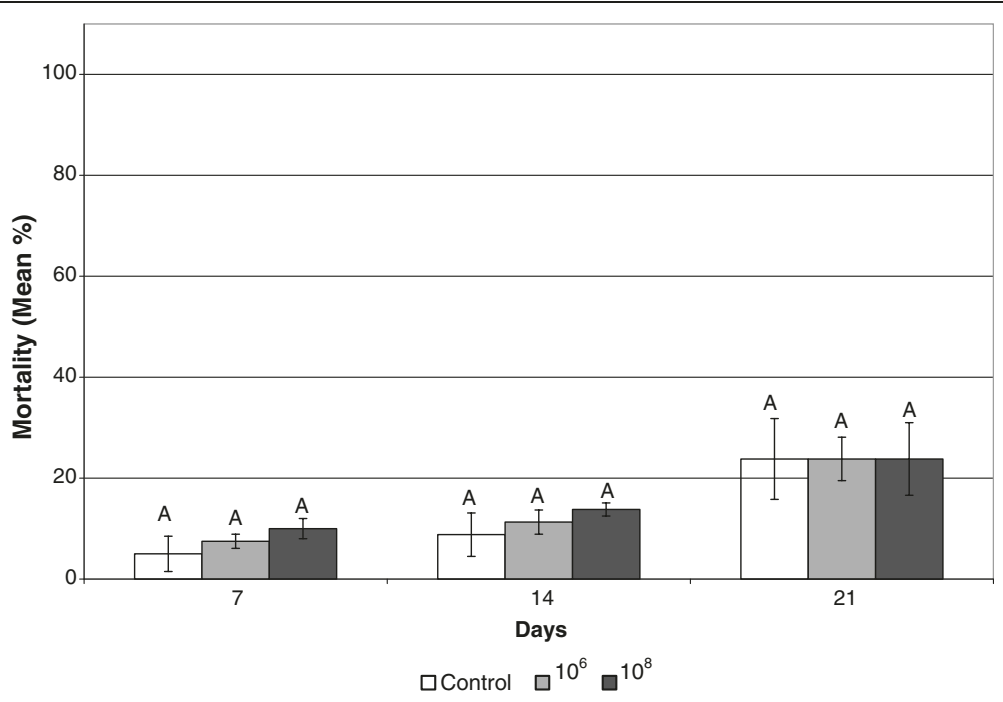

Figure 3 Mean mortality of Formosan subterranean termites by Bacillus thuringiensis spore solutions. Bars on the same day with the same letter are not significantly different.

was significantly different from its respective control. Based on these data the fungi I. fumosorosea and $M$. anisopliae were shown to not be repellent to FST in sand, soil or sawdust.

When termites were exposed to $B$. thuringiensis strain 33679 the effect of both cells and spores was determined.

Table 1 Mean $( \pm$ SEM) number of $C$. formosanus in a paired choice test where tubes were filled with substrate treated with fungal spores at the indicated concentrations, after $24 \mathrm{~h}$ exposure

\begin{tabular}{lcc}
\hline & \multicolumn{2}{c}{ Number of termite in tubes } \\
\cline { 2 - 3 } Treatment & Treated & Control \\
\hline I. fumosorosea $1 \mathbf{1 0}^{\mathbf{6}}$ spores/g & \\
Sand & $36.3 \pm 13.5 \mathrm{a}^{*}$ & $60.2 \pm 17.3 \mathrm{a}$ \\
Soil & $96.1 \pm 11.1 \mathrm{a}$ & $77.4 \pm 10.6 \mathrm{a}$ \\
Sawdust & $92.5 \pm 9.6 \mathrm{a}$ & $72.8 \pm 10.2 \mathrm{a}$ \\
I. fumosorosea $\mathbf{1 0}^{\mathbf{8}}$ spores/g & \\
Sand & $46.0 \pm 6.5 \mathrm{a}$ & $50.8 \pm 4.5 \mathrm{a}$ \\
Soil & $71.3 \pm 16.0 \mathrm{a}$ & $82.7 \pm 17.1 \mathrm{a}$ \\
Sawdust & $49.3 \pm 9.8 \mathrm{a}$ & $56.1 \pm 9.7 \mathrm{a}$ \\
M. anisopliae $10^{\mathbf{6}}$ spores/g & \\
Sand & $23.9 \pm 5.5 \mathrm{a}$ & $45.0 \pm 13.0 \mathrm{a}$ \\
Soil & $82.3 \pm 7.4 \mathrm{a}$ & $76.0 \pm 7.0 \mathrm{a}$ \\
Sawdust & $93.4 \pm 9.2 \mathrm{a}$ & $62.7 \pm 9.3 \mathrm{a}$ \\
M. anisopliae $10^{8}$ spores/g & \\
Sand & $12.3 \pm 2.0 \mathrm{a}$ & $23.0 \pm 5.9 \mathrm{a}$ \\
Soil & $78.3 \pm 12.6 \mathrm{a}$ & $77.6 \pm 12.8 \mathrm{a}$ \\
Sawdust & $31.0 \pm 3.9 \mathrm{a}$ & $36.5 \pm 4.5 \mathrm{a}$ \\
\hline
\end{tabular}

* Values with the same letter are not significantly different, $\mathrm{P} \leq 0.05$.
All treatments were applied at a concentration of $10^{9}$ propagules/g. With cells in sand or soil, the treated tube values were not significantly different from the controls (Table 2). With cells in sawdust, the difference was highly significant with only $29.3 \pm 6.6$ termites remaining in the treated tubes compared with $130.8 \pm 9.6$ in the control tubes (Paired choice t-test). These values indicated that the $B$. thuringiensis cells were strongly repellent to FST in sawdust. FST were also exposed to a $B$. thuringiensis culture in which the cells had formed spores due to nutrient deprivation. Neither the soil nor sawdust treatments were

Table 2 Mean ( \pm SEM) number of $C$. formosanus in a paired choice test where tubes were filled with substrate treated with Bacillus thuringiensis strain ATCC 33679 at a concentration of $10^{9}$ propagules/g, after $24 \mathrm{~h}$ exposure

\begin{tabular}{lll}
\hline & \multicolumn{2}{l}{ Number of termites in tubes } \\
\cline { 2 - 3 } Treatment & Treated & Control \\
\hline Cells & \\
Sand & $43.5 \pm 15.0 a^{*}$ & $66.5 \pm 17.1 \mathrm{a}$ \\
Soil & $51.6 \pm 8.9 \mathrm{a}$ & $82.0 \pm 10.9 \mathrm{a}$ \\
Sawdust & $29.3 \pm 6.6 \mathrm{a}$ & $130.8 \pm 9.6 \mathrm{~b}$ \\
Spores & & \\
Sand & $32.9 \pm 14.3 \mathrm{a}$ & $26.1 \pm 6.7 \mathrm{a}$ \\
Soil & $70.2 \pm 10.6 \mathrm{a}$ & $77.1 \pm 12.2 \mathrm{a}$ \\
Sawdust & $65.8 \pm 7.3 \mathrm{a}$ & $70.5 \pm 13.8 \mathrm{a}$ \\
50\% Cells $+\mathbf{5 0} \%$ Spores & & $88.3 \pm 12.3 \mathrm{~b}$ \\
Sand & $31.5 \pm 4.4 \mathrm{a}$ & $60.3 \pm 12.6 \mathrm{a}$ \\
Soil & $41.1 \pm 8.4 \mathrm{a}$ & $66.8 \pm 12.0 \mathrm{a}$ \\
Sawdust & $66.3 \pm 11.9 \mathrm{a}$ & \\
\hline
\end{tabular}

* Values with the same letter are not significantly different, $\mathrm{P} \leq 0.05$. 
significantly different from the respective controls, indicating that $B$. thuringiensis in these treatments was not repellent to FST. B. thuringiensis was also tested for its effect on FST as a mixture of cells and spores. The culture was incubated in media with a diluted nutrient source and the formation of spores was observed microscopically over time. The termites were exposed when the culture was as close as possible to $50 \%$ vegetative cells and $50 \%$ spores. In sand, the cell/spore treatment resulted in significantly more termites remaining in the control tubes compared with the treated tubes. Neither the soil or sawdust treatments were significantly different from the controls.

\section{Conclusions}

Of the microbes tested, I. fumosorosea demonstrated the highest rate of mortality when termites were exposed to the spores in liquid. This is consistent with previous mortality studies that showed a significant pathogenic effect of this fungus against FST $[8,18]$. In this study $I$. fumosorosea was also found to not repel termites in a paired choice test in sand, soil or sawdust. For any microbial agent to be effective as a termite control agent the cells or spores must not be repellent, as repellency will result in detection and avoidance by the members of the colony [20]. I. fumosorosea has the added advantage of being produced as a stable powder [19]. This fungus has also been formulated in a biologically-compatible foam suitable for application to termite nest environments [9]. The foam has the potential to be used with $M$. anisopliae and other microbial agents.

Of the microbes tested, $B$. thuringiensis cells were found to repel termites only when in sawdust, and in the combination of cells and spores in sand. The remaining treatments, cells in sand and soil; spores in sand, soil and sawdust; and a combination of cells and spores in soil and sawdust, were not repellent to FST. However, when termites were exposed in liquid to the bacterium it was found to not be significantly pathogenic.

Based on the data reported here the fungi tested were found to not be repellent to FST. Both strains are pathogenic to this species of termite and have potential to control it in the field. The Bacillus strain had the lowest rate of mortality and, when exposed as cells in sawdust or as a combination of cells and spores in sand, was repellent to FST. Of the three microbes tested it would be the least likely to be selected for further development. The method reported here can be used to screen other Bacillus strains, and other potential bacterial entomopathogens, for mortality of FST in liquid. Using this method more closely approximates the liquid-based application which will ultimately be used in the field. The fact that the I. fumosorosea and M. anisopliae strains tested were pathogenic to FST and were here found to not repel termites makes them viable candidates for control of FST.

\section{Methods}

Isaria fumosorosea strain ARSEF 3581 was provided as blastospores in a wettable powder formulation with kaolin clay as the inert carrier by Dr. Mark Jackson (NCAUR, Peoria, IL) [19]. Metarhizium anisopliae strain NRRL 30905 (ARS Patent Culture Collection, Peoria, IL, USA) was isolated in this laboratory from dead FST alates [7]. It was inoculated onto potato dextrose agar (PDA) plates and incubated at $25^{\circ} \mathrm{C}$ for $7 \mathrm{~d}$. Spores were harvested from the plates by scraping with a sterile loop. Bacillus thuringiensis Berliner strain ATCC 33679, isolated from diseased insect larvae, was obtained from the American Type Culture Collection (Manassas, VA, USA). A $100 \mu$ l aliquot of cells was removed from a tube stored at $-80^{\circ} \mathrm{C}$ and used to inoculate $10 \mathrm{ml}$ of LB. The culture was incubated at $28^{\circ} \mathrm{C}$ and $225 \mathrm{rpm}$ for approx $6 \mathrm{hr}$, then used to inoculate $100 \mathrm{ml}$ of LB which was incubated at $28^{\circ} \mathrm{C}$ and $225 \mathrm{rpm}$ overnight. To encourage spore formation, a $10 \mathrm{ml}$ culture of B. thuringiensis in LB was used to inoculate $100 \mathrm{ml}$ of LB prepared at $25 \%$ $(\mathrm{w} / \mathrm{v})$ of the manufacturer's standard recipe. The bacterial mass was harvested by centrifugation at $13 \mathrm{krpm}$ for 20 min at $4^{\circ} \mathrm{C}$ in an angle rotor. The pellet was resuspended in water. Fungal spores, and bacterial cells and spores were enumerated using a Levy hemacytometer (0.1 mm deep; VWR, West Chester, PA, USA). B. thuringiensis cultures were determined to have reached $50 \%$ cells $+50 \%$ spores, and $100 \%$ spores by enumeration using the hemacytometer.

Termites were collected from City Park, New Orleans, LA from bucket traps [21]. Four colonies were used for each treatment to prevent colony vitality biasing of data. Twenty FST from each colony were placed into a $2 \mathrm{ml}$ conical microcentrifuge tube containing $0.5 \mathrm{ml}$ of the spore/cell solution for 2 minutes, independent of termites from the other colonies. Tubes were agitated by hand during the incubation time to ensure that the termites were submerged in the liquid. The termites were then transferred to a $90 \mathrm{~mm}$ disc of filter paper (Whatman, Maidstone, England) in the lid of a $100 \times$ $15 \mathrm{~mm}$ Petri dish where they were allowed to air dry. Control termites were exposed as described above, but the microcentrifuge tube contained water only without the addition of spores or cells. The termites were then transferred to a $55 \mathrm{~mm}$ Whatman filter paper disc moistened with water, which served as a moisture and nutrient source, and placed in the lid of a $60 \times 15 \mathrm{~mm}$ Petri dish. Termites were incubated at $25^{\circ} \mathrm{C}$ and $85 \%$ humidity while mortality was monitored.

Termites were kept in the lab in 5.6-L covered plastic boxes containing moist sand and blocks of spruce Picea sp. until they were used in experiments. Treated substrates (sand, soil, or red oak sawdust) were inoculated with the stated concentration of microbe $(w / w)$ and placed 
in a $1 / 2$ gallon plastic bottle (Nalgene, Rochester, NY, USA). The bottle was rotated at $2 \mathrm{rpm}$ ( $80 \%$ motor speed) for 6 hrs on a Wheaton Roller Apparatus (Millville, NJ, USA) at room temperature to ensure even distribution of cells and/or spores prior to transfer to the test containers. Control substrates did not contain any of the microbes.

Treated and control substrates were thoroughly moistened. A soil moisture meter (Spectrum Technologies, Plainfield, IL, USA) was used to establish moisture levels of $80 \%$ saturation for each substrate. Moist treated or control material was placed in $14 \mathrm{ml}(17 \times 100 \mathrm{~mm})$ polystyrene round-bottom Falcon test tubes (Becton Dickinson, Franklin Lakes, NJ, USA). Each tube was filled with $10 \mathrm{ml}$ of material. Tests were conducted using Rubbermaid ${ }^{\mathrm{TM}}$ storage containers $(14.5 \mathrm{~cm} \times 8.5 \mathrm{~cm} \times 4 \mathrm{~cm}$, Consolidated Plastics, Twinsburg, OH, USA) (Figure 4) [22]. Each container contained $100 \mathrm{~g}$ of sand (Standard Sand and Silica Company, Davenport, FL, USA) moistened with $20 \mathrm{ml}$ of water. Each container had a $2 \mathrm{~cm}$ diameter hole on each side. A test tube was inserted into each hole and sealed in place using hot glue from a glue gun. For each container, there were two treatment tubes, which contained substrate treated with the stated microbe, and two control tubes, which contained substrate only. Because termites tend to aggregate, this experimental design reduced the probability that all of the termites would randomly aggregate in a single tube. Aggregation would impact the ability to attribute termite behavior to repellency [22]. The position of treatment and control tubes was alternated between replicates to preclude any positional effects. For each replicate, 200 termites (190 workers: 10 soldiers) were placed in the center of the container. Termites were able to move freely between the container and the tubes.

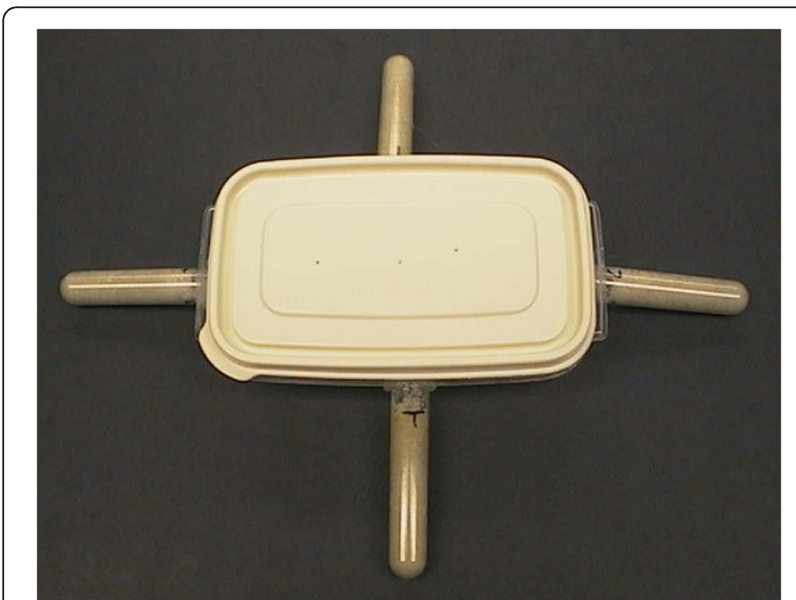

Figure 4 Bioassay unit composed of a plastic container $(14.5 \times$ $8.5 \times 4 \mathrm{~cm}$ ) filled with $100 \mathrm{~g}$ of moistened sand, connected to four $14 \mathrm{ml}$ polystyrene round bottom test tubes $(17 \times 100 \mathrm{~mm})$ containing either treated (two tubes) or control (two tubes) substrate.
For each experiment there were 12 replicates; four different colonies, with three replicates of each colony. Containers were kept in a dark environmental chamber at $28^{\circ} \mathrm{C}$, $97 \% \mathrm{RH}$ for $24 \mathrm{~h}$. After $24 \mathrm{~h}$, rubber stoppers were placed over the opening of each tube to prevent termites from leaving the tube while being counted. Each tube was removed from the container and all of the termites in each tube were counted. Numbers of termites in treated or control tubes for each replicate were determined.

For mortality bioassays, data were analyzed using analysis of variance (ANOVA) and least significant difference (LSD) at $\mathrm{P} \leq 0.05$ [23]. All analyses were run using SAS Software. For repellency bioassays, differences in the number of termites in treated or control tubes were compared using a paired choice t-test.

Mention of trade names or commercial products in this article is solely for the purpose of providing specific information and does not imply recommendation or endorsement by the U.S. Department of Agriculture.

\section{Competing interests}

The authors are employed by the organization that funded the project. The authors do not hold stock or shares in an organization that may benefit financially from the publication of this manuscript. No patents relating to this work are being applied for. The authors have no non-financial competing interests.

\section{Authors' contributions}

MW carried out all microbial strain maintenance and propagation, mortality bioassays, and preparation of treated substrates. MC carried out all termite collection and maintenance, and repellency bioassays. MW and MC both analyzed statistics for their respective data.

\section{Acknowledgments}

This study was funded by the United States Department of Agriculture, Agricultural Research Service. The authors wish to thank Bridgette Duplantis, Erin Lathrop and Christopher Florane for technical assistance.

\section{Author details}

'United States Department of Agriculture, Southern Regional Research Center, New Orleans, Louisiana, USA. ${ }^{2}$ United States Department of Agriculture, Beltsville Agricultural Research Center, Beltsville, Maryland, USA.

Received: 17 September 2012 Accepted: 22 November 2012 Published: 15 December 2012

\section{References}

1. Culliney TW, Grace JK: Prospects for the biological control of subterranean termites (Isoptera: Rhinotermitidae), with special reference to Coptotermes formosanus. Bull Entomol Res 2000, 90:9-21.

2. Grace JK: Approaches to biological control of termites. Sociobiol 2003, 41:115-121

3. Milner R: Application of biological control agents in mound building termites (Isoptera: Termitidae) - Experiences with Metarhizium in Australia. Sociobiol 2003, 41:419-428.

4. Myles TG: Alarm, aggregation, and defense by Reticulitermes flavipes in response to a naturally occurring isolate of Metarhizium anisopliae. Sociobiol 2002, 40:243-255.

5. Sun JZ, Fuxa JR, Richter A, Ring D: Interactions of Metarhizium anisopliae and tree-based mulches in repellence and mycoses against Coptotermes formosanus (Isoptera: Rhinotermitidae). Env Entomol 2008, 37:755-763.

6. Maketon M, Sawangwan P, Sawatwarakul W: Laboratory study on the efficacy of Metarhizium anisopliae (Deuteromycota: Hyphomycetes) in controlling Coptotermes gestroi (Isoptera: Rhinotermitidae). Entomol Gen 2007, 30:203-218. 
7. Wright MS, Raina AK, Lax AR: A strain of Metarhizium anisopliae for controlling subterranean termites. J Econ Entomol 2005, 98:1451-1458.

8. Wright MS, Connick WJ, Jackson MA: Use of Paecilomyces spp. as pathogenic agents against subterranean termites. 2003:1-17. US Patent No. 6660291.

9. Dunlap CA, Jackson MA, Wright MA: A foam formulation of Paecilomyces fumosoroseus, an entomopathogenic biocontrol agent. Biocontrol $\mathrm{SC}$ Technol 2007, 17:513-523.

10. Dunlap CA, Jackson MA, Wright MA: Compositions of keratin hydrolysate and microbes for pest control applications. 2012:1-12. US Patent No. 8263526.

11. Luangsa-Ard JJ, Hywel-Jones NL, Manoch L, Samson RA: On the relationships of Paecilomyces sect. Isarioidea species. Mycol Res 2005, 109:581-589.

12. de Castilhos-Fortes R, Matsumura ATS, Diehl E, Fiuza LM: Susceptibility of Nasutitermes ehrhardti (Isoptera: Termitidae) to Bacillus thuringiensis subspecies. Braz J Microbiol 2002, 33:219-222.

13. Mathew GM, Lin SJ, Chang JJ, Huang CC: DGGE detection and screening of lignocellulolytic bacteria from the termite gut of Coptotermes formosanus. Malays J Microbiol 2011, 7:201-209.

14. Yanagawa A, Yokohari F, Shimizu S: The role of antennae in removing entomopathogenic fungi from cuticle of the termite, Coptotermes formosanus. J Insect Sci 2009, 6:1-9.

15. Yanagawa A, Shimizu S: Resistance of the termite, Coptotermes formosanus Shiraki to Metarhizium anisopliae due to grooming. BioControl 2007, 52:75-85.

16. Yanagawa A, Yokohari F, Shimizu S: Defense mechanism of the termite, Coptotermes formosanus Shiraki, to entomopathogenic fungi. J Invertebr Pathol 2008, 97:165-170.

17. Su NY, Scheffrahn RH: A review of subterranean termite control practices and prospects for integrated pest management programmes. Integr Pest Manag Rev 1998, 3:1-13.

18. Wright MS, Connick WJ Jr, Jackson MA: Use of Paecilomyces spp. as pathogenic agents against subterranean termites. 2008:1-15. U.S. Patent No. 7390480.

19. Jackson MA, Mcguire MR, Lacey LA, Wraight SP: Liquid culture production of desiccation tolerant blastospores of the bioinsecticidal fungus Paecilomyces fumosoroseus. Mycol Res 1997, 101:35-41.

20. Staples JA, Milner RJ: A laboratory evaluation of the repellency of Metarhizium anisopliae conidia to Coptotermes lacteus (Isoptera: Rhinotermitidae). Sociobiol 2000, 36:133-148.

21. Su NY, Scheffrahn RH: A method to access, trap, and monitor field populations of the Formosan subterranean termite (Isoptera: Rhinotermitidae) in the urban environment. Sociobiol 1986, 12:299-304.

22. Cornelius ML, Daigle DJ, Connick WJ, Parker A, Wunch K: Responses of Coptotermes formosanus and Reticulitermes flavipes (Isoptera: Rhinotermitidae) to three types of wood rot fungi cultures on different substrates. J Econ Entomol 2002, 95:121-128.

23. Cody RP, Smith JK: Applied Statistics and the SAS Programming Language. NJ: Prentice-Hall Inc; 1997.

doi:10.1186/1471-2180-12-291

Cite this article as: Wright and Cornelius: Mortality and repellent effects of microbial pathogens on Coptotermes formosanus (Isoptera: Rhinotermitidae). BMC Microbiology 2012 12:291.

\section{Submit your next manuscript to BioMed Central and take full advantage of:}

- Convenient online submission

- Thorough peer review

- No space constraints or color figure charges

- Immediate publication on acceptance

- Inclusion in PubMed, CAS, Scopus and Google Scholar

- Research which is freely available for redistribution 